\title{
A Case Study of the Use of Wikipedia among English Department Students of Andalas University
}

\author{
${ }^{1}$ Hanafi \\ Faculty of Humanities - Andalas University \\ ${ }^{2}$ Dian Rianita \\ Fakultas Ilmu Administrasi - Universitas Lancang Kuning \\ dianrianita@unilak.ac.id \\ *Corresponding Author \\ Email: hanafi@hum.unand.ac.id
}

\begin{abstract}
This article reports an investigation of university students' use of online Wikipedia site in writing their assignment or research report. Data were collected through a survey questionnaire and interview. First of all, a survey questionnaire was distributed among the learners $(n=70)$ identifying their computer and internet literacy, frequency, strategy, and future orientation of using Wikipedia for their writing assignments or essays. Then, interviews with some lecturers $(N=8)$ revealed teachers' lack of awareness and agreement of Wikipedia in academic writing, partially due to the absence of Departmental policy. As the results, despite being already informed of the encyclopedia's academic unreliability, Indonesian EFL informants in this study were proven to be familiar with computer and capable of using internet and incorporating Wikipedia materials when writing their essays at Andalas University. The data also indicated that students had improved their techniques of using the Wikipedia from copying-and-pasting to editing and paraphrasing. Half of them did not cross check Wikipedia article's citations and references. Therefore, students' awareness of the ease of Wikipedia may have encouraged them to consciously plagiarize in addition to the absence of their lecturers' awareness upon this issue.
\end{abstract}

Keywords: Wikipedia, citing, plagiarism, academic writing, EFL learners

\section{INTRODUCTION}

As a web-based encyclopedia, Wikipedia has been increasingly acquiring more users and fans all over the world since its inception in 2001. The online encyclopedia is greatly benefitted from the ongoing rapid development of communication technologies such as broader internet and computer access facilities around the world. Its vast number of articles written in English (over 2,777,368) and visitors (at least 9,118,650 registered users) have make it the largest online encyclopedia (Baron, 2008) and one of the most visited websites in the world (Wilkinson \& Huberman, 2007; Blumenstock, 2008). This web's popularity attracts many kinds of users ranging from encyclopedic addicts to academic experts to add or modify its contents (Den Besten, Loubser, \& Dalle, 2008). This perhaps becomes one of the reasons for its rapid growth. As the result, Wikipedia has turned into the most convenient website for all kinds of users to get fast information for any purpose, including completing academic essays or papers.

As to the use of Wikipedia as reference in academic essays, some research 
(James \& McInnes, 2001; O’Connor, 2002; Sutherland-Smith, 2008; Zobel \& Hamilton, 2002) discovered that most students have greatly used unreliable internet sites including Wikipedia as a source of academic information and references for their college papers. The students simply benefit from google or other search engines for their search of information. This is mostly due to the ease and the speed of Wikipedia for students who are coping with their 'school-work' tasks. Since the goal of such online encyclopedia is to provide objective knowledge (Baron, 2008, p.120), students and other users may find it as a good quick source for their academic information in replacement of accessing the expensive and heavilycredential academic papers such as printed scholarly journals or academic textbooks.

However, the Wikipedia's use in academic writing is not without challenge. Like any other encyclopedias, Wikipedia are mostly not admitted to be used in almost all academic and higher educational institutions. Students who write their theses are expected to cite from more academically credible sources such as scholarly peer-reviewed journals, academic textbooks, and handbooks published by credible publishers. Some universities (e.g. Wentz \& Sharma, 2007) though allow their students to use Wikipedia appropriately in their assignments. Nevertheless, there are more cases where students reported their failed essays because of citing from Wikipedia.

This paper presents an investigation which is conducted to see how English Department students of Andalas University of West Sumatera, Indonesia, use Wikipedia in writing their academic essays in spite of being heavily warned over the risk of its usage in their academic writings. This paper will start with a brief review of the issue on the reliability of articles posted in the online encyclopedia. Then, the use of Wikipedia in students' academic writing in Andalas University proceeds and precedes a short overview on the university's EFL learning scheme. Afterwards, objectives of this paper are presented and followed by result, discussion, implications, and conclusion sections. A self-reflection on the limitations of this study ends the paper.

\section{The issue of Wikipedia's reliability as academic source or citation / reference}

Actually, Wikipedia's academic reliability or encyclopedic neutrality has clearly been indicated by the web's administrators or editors in the web's articles / sections through their tags such as:

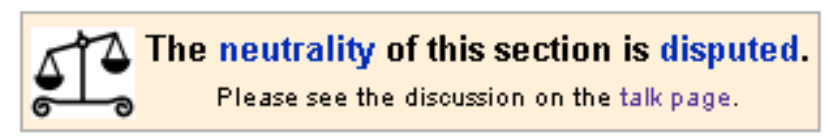

and

Adopted from Wikipedia

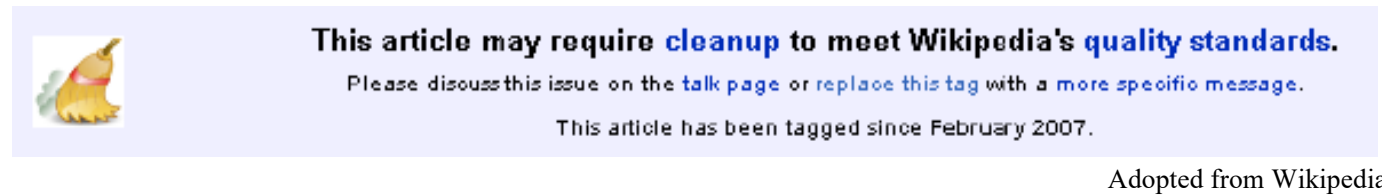

Additionally, Jimmy Wales, the founder of Wikipedia, has ever warned students not to refer to Wikipedia (Orlowski, 2006) especially for academic use. In light of 
this academic unreliability, there is a caution that college students in particular should not use articles in Wikipedia as primary citable sources. It is clearly stated on the site that, '...Citation of Wikipedia in research papers has been known to result in a failing grade...' (Researching with Wikipedia, 2009, Citing Wikipedia, para.1). Many cases of students' failure due to simply citing from Wikipedia should have added to the making of a strong argument that it is really not preferable for college students to cite from Wikipedia in their academic essays.

However, for some people who are working in engineering, computer, and information technology areas and in favor of developing open source software, such problem of Wikipedia's articles' academic quality presents a particular challenge. Some researchers try to improve quality of Wikipedia (e.g. Adler et al., 2007), investigate the web's articles' scientific citations (Nielsen, 2007), and attempt to assess the quality of Wikipedia's article through word count (Blumenstock, 2008). Another study (Demartini, 2007) also proposes a particular methodology in searching experts in Wikipedia through the content or among the web's users. Although these studies do not seem to explicitly support the side that Wikipedia should be given a credit as an academically citable source of references, the studies indicate that there are a number of people who may be holding hopes that Wikipedia one day may attain a certain degree of academic trust. Some works also make use of Wikipedia as a medium for pedagogic project (Foss et al., 2007) and collaborative problem-solving network (Den Besten, Loubser, \& Dalle, 2008). These works affirm that there is a great potential for this one of the most visited online encyclopedias to increase its academic and encyclopedic quality in keeping up with its rapid development of popularity.

By considering all sides of the story, this present paper specifically favors the argument that student (of English Department in particular) must not quote, refer, or cite from Wikipedia. With all due respects to the side favoring the use of Wikipedia as an academically reliable source of references, the writer of this present paper discovers that the ease Wikipedia offers to student would drive the alreadylow-motivated students and tempt even the mediocrely-motivated learners to get lazier and more practical. One must not take such laziness as similar to ignorance and stupidity because the students seem to be smart enough in modifying their way of plagiarizing Wikipedia, as later on found in this study. This indicates that most students of the department in general seem to be intelligent but greatly undermotivated and totally practical. What needs to be done accordingly is to motivate and assure them to exploit their own capacity and potentials. Lecturers may have to strongly encourage them to read directly from academically reliable primary sources such as books, scholarly journal articles, seminar proceedings, etc. Their efforts of reading from these sources should be highly appreciated and well-marked. In light of educational purpose, the effort of simply reading from encyclopedia, especially the online ones, may need to be less appreciated and discouraged because it feeds them with temptations to simply be practical and do copy-and-paste activity in their assignment.

However, if students have proved that they have done sufficient readings from primary sources, their critical commentaries on the reliability of the information given in Wikipedia's articles could then be expected and would consequently be highly appreciated. Thus, they may use Wikipedia just as the starting point to get more references and return to the encyclopedia's article for confirming the quality 
of its article. Consequently, if the department's students do this cross-check-andconfirming activity upon Wikipedia's articles on a regular basis, they may as well turn to become trusted contributors or administrator for this online encyclopedia (Den Besten, Loubser, \& J-M Dalle, 2008). This is how students in academic writing class are expected to do when using Wikipedia in their writing.

\section{English Department at Andalas University}

Like any other Indonesian state universities, Andalas University (Unand) naturally uses Indonesian as the language of instruction and assessment in almost all of its departments. Within such language policy, all paperworks and assignments submitted by students must be written in Indonesian. However, by using English as the language of instruction, students of English department are required to excellently master the four language skills (reading, listening, speaking, and writing) specifically in English in order for them to be distinct from other language departments' (i.e. Minangkabau, Indonesian, and Japanese) students. In addition to carrying out an academically critical and deep analysis on linguistic, applied linguistics, or literary issues on English, students are accordingly expected to demonstrate altogether excellent oral and written presentations in both English and Indonesian.

With these objectives in mind, English Department's graduates are projected to be in the capacity of assessing linguistic products of English language and (either native or non-native) speakers of the English language. Based on their academic competence, they should be the ones who are eligible to produce recommendations from linguistic, applied linguistic, and sociolinguistic perspectives. In short, English Department graduates can use English in the four modalities, analyze the English language being used by others, and thus provide, at least initial, professional assistance for others to acquire English language skills for academic and specific purposes.

\section{Wikipedia and academic writing at English Department of Andalas University}

Up to this moment, there still has been no departmental or even university's written policy on committing citation or referencing from encyclopedia at Andalas University. Unlike many departments (e.g. Cohen, 2007) in many universities in the world, Andalas University has not yet formulated any policy to anticipate such potentials of electronic plagiarism. Some lecturers of English Department have started to be aware of this issue and apply their own policy in their classes. Few lecturers teaching such classes as Academic Writing, Linguistics/Literary Research Methods, Seminar on Linguistics/Literature, and some other content subject classes specifically warn their students not to cite from Wikipedia in the first place. According to the lecturers, the students still cite from the site. Even though the university has currently applied Turnitin check as the required plagiarism detection procedure for thesis submission, it does not stop students from citing from Wikipedia because an explicit and elaborative policy that prevents students from citing any encyclopedia in their academic papers still has not put in place.

Through a longitudinal teacher observation, there is an indication that English Department's students of Unand have become highly aware of Wikipedia. Some lecturers who respectively teach content subjects frequently report that some students, despite being already warned, still commit plagiarism. In line with what 
many studies have indicated (James \& McInnes, 2001; O’Connor, 2002; Zobel \& Hamilton, 2002), the use of electronic media such as internet as the easiest and fastest source for plagiarism has been significantly increasing at higher educational institutions, including at Andalas University.

\section{Research Objectives}

There are three objectives of this study:

1. To identify students' computer and internet browsing literacy

2. To identify students' familiarity, frequency, and strategies of using Wikipedia in their academic writings

3. To identify lecturers' role and awareness of Wikipedia in their student essays

\section{METHOD}

This paper was primarily based on a longitudinal teacher observation, a survey questionnaire distributed among, and interviews with some students and lecturers of English Department. The researchers' observation as a teacher / lecturer in writing classes plays a very important role in defining points in the survey questionnaire. Since the researcher of this study also taught Academic Writing subject, students who participated in this study should not feel that their writing strategy was being investigated by the department. This factor may either trigger their reluctance to provide the true answer or create 'Hawthorne effect' (Mackey \& Gass, 2005). Consequently, data collection was carried out by two research assistants (who were students too). Then, interviews with some students and lecturers of the department presented a more qualitative picture of the academic writing situation in the department. As the results, analysis from sample data of already-marked student essays collected from the lecturers can justify the information generated by students and lecturers through questionnaire and interviews.

\section{Participants}

Since there were more than 500 registered students in the department twofifth of which have not yet taken the Academic Writing class, it was necessary to use stratified random sampling procedure upon the department's student population. Students from 2006, 2005, and 2004 classes were recruited as the participants because they have taken academic writing class which was the inclusive criteria for informants to participate in this research. Data were randomly collected from each of the three classes through a survey questionnaire distributed to 70 participants ( 44 students of 2006 class, 15 of 2005 class, and 11 of 2004 class). The questionnaire was given to the students in their lunch and spare time in one day. From all students being offered, these 70 participants willingly volunteered as student informants in this research project.

In addition, there were eight out of 30 lecturer informants participating in this research. Interviews were conducted upon them in their spare times, e.g. class breaks, lunch breaks, prior to department's meetings, etc. The department had 30 registered lecturers who serve around 500 to 600 students. Four of them were pursuing their higher degree (master and doctor). Among the remaining, there were only 20 teaching staff members who were actively serving at the department. Others 
were stationed at other institutions and attended the department simply for their occasional classes. The lecturer informants were four junior lecturers aged 26 to 31 and another four senior lecturers aged above 35. Among them, there was only one lecturer who was still holding an undergraduate degree when being interviewed. Unfortunately, these lecturers could not provide samples of their students' writings using Wikipedia's source because of having returned them to the students. Therefore, samples of students' writings were taken simply from the Academic Writing class the researchers were holding.

\section{Instruments}

The primary instrument for data collection was a survey questionnaire. The questionnaire consists of four sections. The first section consists of five sub-points covering the student's registered number, age, sex, current year at Unand, and first language. The second section comprises five items identifying their regular access to computer, skills for using MS Word and MS Excel, and browsing literacy. This section was measured using Likert Scale but only in four points. The third section contains eight items which investigates participants' familiarity of using internet in completing and sending their assignments. The fourth section comprises items investigating the students' familiarity, strategies, experiences, and future plan of using online encyclopedia in their assignments. To avoid 'fatique effect' (Dornyei, 2003, p.14), the two-page questionnaire was printed both sides on a quarto size paper.

Two weeks after filling in the questionnaire, some participants and lecturers of the department were interviewed. The given questions for students were around their assessment on Wikipedia as an academically reliable source of information and their strategies of using it in their assignments. The interview was meant to be a qualitative comparison for the answer they had previously provided in the survey questionnaire. Questions for the lecturers encompassed their awareness of electronic plagiarism in their students' essays, their methods of teaching the students not to commit it, and their perspective on using Wikipedia in particular and any other encyclopedia in general for academic essays. Through the interview, the general picture of English department's lecturers' electronic plagiarism policy could emerge. Therefore, this very study could be used to promote the establishment of an (electronic) plagiarism policy in the department.

\section{Procedures}

In order to avoid the intervening variable of teacher-student relationship, halo and Hathorne effects, two students (Putri Vadisa Herman from 2006 class and Indriana Ningsih from 2005 class) were involved and trained to collect data from student informants. Each of them represented their classmates participating in the study. Herman was assigned to collect data from her 2006 classmates. Ningsih who happened to have a broader social network with her senior fellow-students managed to collect data not only from her 2005 classmates but also 2004 class students. Nevertheless, Ningsih could only collect data from 26 participants (15 from 2005 and 11 from 2004), while Herman could collect data from 44 participants from 2006 class only. The reason for senior students' lack of participation may be due to their preoccupation with their thesis or research proposals. Most of the 2004 and 2005 students were preparing themselves to graduate from the department immediately 
while the 2006 students were still in the middle of their college period and not so much busy with such serious tasks as thesis writing.

Having been collected, the data were statistically processed and analysed. Since most items in the questionnaire were closed-ended, frequency of the students' response to question items was counted in percentage and presented in table. Therefore, participants' frequency of using Wikipedia could be identified. The data were then clarified by results of the interview with students and lecturers. Finally, examples of students' strategy in incorporating information they obtained from Wikipedia into their essays were presented. The quality of the paper was also assessed, partially on the basis of the mark given by the lecturer.

\section{RESULTS}

\section{Computer Literacy and Internet Browsing Skill}

In terms of computer literacy (Table 1), $65.7 \%$ of informants answered that they were using computer in the category of 'good' (out of not so good, very good, good, and not good categories). There were 18 participants $(25.7 \%)$ who confidently categorized themselves as very-good computer users when completing their assignment. None of the participants answered that they were not good users. Additionally, there were only five (7.1\%) participants who assessed themselves as not-so-good computer users.

Table 1. Computer Literacy

\begin{tabular}{|l|r|r|}
\hline \multicolumn{2}{|c|}{$\begin{array}{c}\text { How good are you at using computer for } \\
\text { completing your assignment? }\end{array}$} \\
\hline \multicolumn{1}{|c|}{ Scale } & Frequency & \multicolumn{1}{c|}{ Percent } \\
\hline Not So Good & 5 & 7.1 \\
Good & 46 & 65.7 \\
Very Good & 18 & 25.7 \\
\hline Total & 69 & 98.6 \\
\hline
\end{tabular}

When asked about their typing skills using MS Word and MS Excel software packages, more participants, in general, assessed themselves to have better skills at using MS Word rather than MS Excel (Table 2). Only five students admitted that they were not so good at using MS Word but ten students $(14.3 \%)$ admitted that they were not good at using MS Excel, and 32 participants $(45,7 \%)$ answered that they were not so good at operating MS Excel.

Table 2. Computer Literacy

\begin{tabular}{|l|r|r||l|r|r|}
\hline \multicolumn{2}{|c|}{ How good are you at using MS Word? } & \multicolumn{2}{c|}{ How good are you at using MS Excel? } \\
\hline \multicolumn{1}{|c|}{ Scale } & Frequency & \multicolumn{1}{c|}{ Percent } & Scale & Frequency & \multicolumn{1}{c|}{ Percent } \\
\hline Not Good & 0 & 0 & Not Good & 10 & 14.3 \\
Not So Good & 5 & 7.1 & Not So Good & 32 & 45.7 \\
Good & 41 & 58.6 & Good & 25 & 35.7 \\
Very Good & 24 & 34.3 & Very Good & 3 & 4.3 \\
\hline Total & 70 & 100.0 & Total & 70 & 100.0 \\
\hline
\end{tabular}

In the item inquiring participant's internet browsing skill, there was a variety of answer. Despite only one participant admitting to be not good at 
browsing, there were 13 participants who was confident that they were not so good at it. Most participants believed that they had much better a browsing skill (very good 35\% and good 44\%). Despite such variety, they all had already got email addresses and used internet to find source material for their assignment (Table 3).

Table 3. Internet Browsing Skill

\begin{tabular}{|c|c|c|c|c|c|}
\hline \multicolumn{3}{|c|}{ How good are you at browsing internet? } & \multicolumn{3}{|c|}{ Do you have an email address? } \\
\hline Scale & Frequency & Percent & Scale & Frequency & Percent \\
\hline Not Good & 1 & 1.4 & No & 1 & $\overline{1.4}$ \\
\hline Not So Good & 13 & 18.6 & Yes & 68 & 97.1 \\
\hline Good & 31 & 44.3 & Total & 69 & 98.6 \\
\hline Very Good & 25 & 35.7 & & & \\
\hline Total & 70 & 100.0 & & & \\
\hline
\end{tabular}

Table 4. Using and citing materials from internet

\begin{tabular}{|c|c|c|}
\hline \multicolumn{3}{|c|}{$\begin{array}{c}\text { Do you cite and refer when using material from } \\
\text { internet for your assignment? }\end{array}$} \\
\hline Scale & Frequency & Percent \\
\hline No & 8 & 11.4 \\
\hline Yes & 61 & 87.1 \\
\hline Total & 69 & 98.6 \\
\hline
\end{tabular}

In the table 4 , it is clearly seen that the majority of the participants $(87,1 \%)$ ever cited and referred to materials they got from internet when making their assignment. There were only eight $(11,4 \%)$ students who admitted to have never got help from internet for their assignment. In closing the inquiry for participants' computer literacy and internet browsing skill, Table 5 shows the student's frequency of using materials from internet to complete their assignment. There were only four students who admitted to have used more than $81 \%$ materials from internet in their assignment. In the bottom level, there were also few students (three) who used 11$30 \%$ internet materials in their college works. The highest frequency level was where there were 20 students admitting to use $41-50 \%$ internet materials, 14 students using $51-60 \%$, and 11 students using $61-70 \%$ of the internet materials in their assignments. Equal numbers (respectively nine) of students answered that they used $31-40 \%$ and $71-80 \%$ internet materials in completing their college assignment.

Table 5 - Frequency of using materials from internet

\begin{tabular}{|c|r|r|}
\hline \multicolumn{3}{|c|}{$\begin{array}{c}\text { In percentage, how often do you use } \\
\text { materials from internet? }\end{array}$} \\
\hline Scale & Frequency & Percent \\
\hline $91-100 \%$ & 2 & 2.9 \\
$81-90 \%$ & 2 & 2.9 \\
$71-80 \%$ & 9 & 12.9 \\
$61-70 \%$ & 11 & 15.7 \\
$51-60 \%$ & 14 & 20.0 \\
$41-50 \%$ & 20 & 28.6 \\
$31-40 \%$ & 9 & 12.9 \\
$21-30 \%$ & 2 & 2.9
\end{tabular}


Journal of English Teaching Adi Buana, Vol. 06 No. 02, October 2021

\begin{tabular}{|l|r|r|}
$11-20 \%$ & 1 & 1.4 \\
\hline Total & 70 & 100.0 \\
\hline
\end{tabular}

\section{Familiarity and Frequency of Using Wikipedia in Assignment}

Table 6. Frequency of using online encyclopedia in assignment

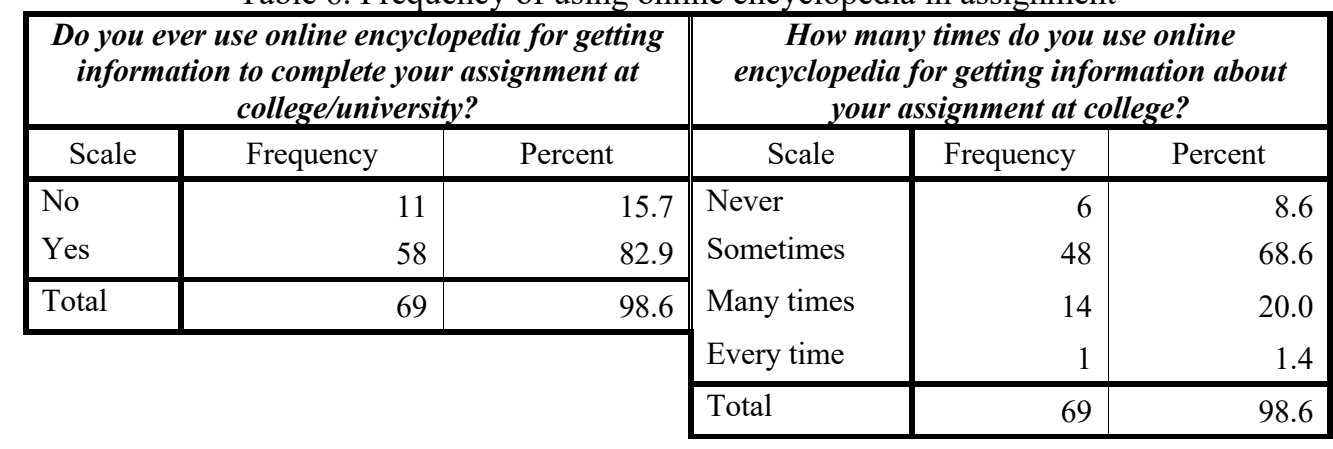

Table 7. Familiarity of using Wikipedia

\begin{tabular}{|l|r|r||}
\hline \multicolumn{2}{|c|}{ What online encyclopedia that you commonly access } \\
for information? \\
\hline Scale & \multicolumn{1}{|c|}{ Frequency } & \multicolumn{1}{c|}{ Percent } \\
\hline Stanford Encyclopedia of & 3 & 4.3 \\
Philosophy & 3 & 4.3 \\
Microsoft Encarta & 32 & 45.7 \\
Wikipedia & 38 & 54.3 \\
\hline Total & & \\
\hline
\end{tabular}

To investigate students' frequency of using Wikipedia, preliminary questions concerning their frequency of using any online encyclopedia shows that $82,9 \%$ students in this study used online encyclopedia for getting information to complete their college assignments. However, in terms of frequency, only $68 \%$ participants answered that they accessed online encyclopedia occasionally or sometimes (Table 6). In table 7 , Wikipedia was the most commonly-visited $(45.7 \%)$ online encyclopedia for the students in this study compared to the other encyclopedias. Furthermore, more of these frequent visitors of online encyclopedia $(81.4 \%$ or 57 students) admitted that they were familiar with accessing Wikipedia and made use of the web encyclopedia (82.9\%) in completing their assignment (Table 8).

Table 8. Familiarity of using Wikipedia

\begin{tabular}{||l|r|r|l|r|r|}
\hline \multicolumn{3}{||c|}{$\begin{array}{c}\text { Are you familiar with accessing } \\
\text { Wikipedia? }\end{array}$} & \multicolumn{2}{c|}{$\begin{array}{c}\text { Do you ever use Wikipedia in completing } \\
\text { your written assignment? }\end{array}$} \\
\hline Scale & Frequency & Percent & Scale & Frequency & \multicolumn{1}{c|}{ Percent } \\
\hline no & 13 & 18.6 & & 12 & 17.1 \\
& 57 & 81.4 & yes & 58 & 82.9 \\
yes & 70 & 100.0 & Total & 70 & 100.0 \\
\hline Total & & & & & \\
\hline
\end{tabular}


Students' Perspective on Wikipedia's Credibility

Table 9 - Students' Perspective on Wikipedia's credibility

\begin{tabular}{|c|c|c|c|c|c|}
\hline \multicolumn{3}{|c|}{$\begin{array}{l}\text { Do you ever use Wikipedia in } \\
\text { completing your written assignment? }\end{array}$} & \multicolumn{3}{|c|}{ Do you ever use Wikipedia in completing your written assignment? } \\
\hline Scale & Frequency & Percent & Measures & Frequency & Percent \\
\hline No & 12 & 17.1 & \multirow{7}{*}{$\begin{array}{l}\text { It is the fastest and easiest references } \\
\text { It is the academically reliable source of } \\
\text { reference } \\
\text { It is the initial information about } \\
\text { content subjects } \\
\text { It is the latest information about content } \\
\text { subjects } \\
\text { It becomes sources of references for my } \\
\text { assignment } \\
\text { all } \\
\text { all but non academically reliable source }\end{array}$} & 15 & 21.4 \\
\hline Yes & 58 & 82.9 & & 12 & 17.1 \\
\hline Total & 69 & 98.6 & & 3 & 4.3 \\
\hline & & & & 3 & 4.3 \\
\hline & & & & 6 & 8.6 \\
\hline & & & & 18 & 25.7 \\
\hline & & & & 4 & 5.7 \\
\hline & & & Total & 61 & 87.1 \\
\hline
\end{tabular}

As closely related to table 6 , table 9 shows clearer indication that the online encyclopedia they frequently $(82.9 \%)$ used in completing their assignment is Wikipedia. To measure their perspective on this Wikipedia's academic reliability, five questions were given in which they could choose more than one. Among those questions, there was only one that explicitly represented the participants' assessment on the academic reliability of the web. As seen in the table, there were 12 participants (17.1\%) out of 61 who answered that it was an academically reliable source of information. More of them voted for all perspectives $(25.7 \%)$. There were only four participants that singled out the option of favoring the web's academic reliability when choosing all others. The more practical students $(21.4 \%)$ chose Wikipedia because of the speed and ease it offered.

\section{Students' Strategies in Using Wikipedia in their Assignment}

Furthermore, when answering questions concerning strategies in using Wikipedia in their assignment, more participants (17 informants) of this study refused to answer. From those who gave their answers, there were 17 informants who simply quoted without citing when using Wikipedia in their assignment. One informant simply did copying-and-pasting; four participants edited after copying and pasting Wikipedia materials; and 12 students managed to further paraphrase the copied-and-pasted-and-edited Wikipedia material in their assignments. The remaining $36 \%$ of them admitted that they did cite if using materials from Wikipedia in their papers. The most common way (30\%) the participants took when using Wikipedia's material was by committing all previous processes and finally citing them.

Table 10. Students' Strategies in using Wikipedia in their assignment

\begin{tabular}{|l|r|r|}
\hline \multicolumn{3}{|c|}{$\begin{array}{c}\text { In what way do you use materials from Wikipedia to } \\
\text { complete your assignment? (Please choose only the only } \\
\text { common way you usually use) }\end{array}$} \\
\hline \multicolumn{1}{|c|}{ Measures } & Frequency & Percent \\
\hline $\begin{array}{l}\text { I copy and paste into the } \\
\text { assignment }\end{array}$ & 1 & 1.4 \\
I copy, paste, and edit & 4 & 5.7
\end{tabular}




\begin{tabular}{|l|r|r|} 
I copy, paste, edit, and & 12 & 17.1 \\
paraphrase & 21 & 30.0 \\
I copy, edit, paraphrase, cite & 8 & 11.4 \\
I quote and cite & 7 & 10.0 \\
\hline I cite & 53 & 75.7 \\
\hline Total
\end{tabular}

Table 11. Students' cross-checking activity upon credibility of Wikipedia's article' links \& references

\begin{tabular}{|l|r|r||r|r|r|}
\hline \multicolumn{3}{|c|}{$\begin{array}{c}\text { Do you ever find or further read } \\
\text { books that are suggested to be read or } \\
\text { referred to by articles that you read } \\
\text { from Wikipedia? }\end{array}$} & $\begin{array}{r}\text { Do you ever recheck the content of the } \\
\text { articles that you read from Wikipedia with } \\
\text { the books written by the academic experts? }\end{array}$ \\
\hline Scale & Frequency & Percent & Scale & Frequency & Percent \\
\hline No & 25 & 35.7 & No & 25 & 35.7 \\
\hline Yes & 39 & 55.7 & Yes & 36 & 51.4 \\
\hline Total & 64 & 91.4 & Total & 61 & 87.1 \\
\hline
\end{tabular}

From all participants (58 persons) who admitted to ever use Wikipedia in their academic essays (Table 9), 39 of them admitted that they ever further found and read books suggested or referred to by the Wikipedia's article they were citing (Table 11). Around similar number of participants (36 students) informed that they rechecked the content of the Wikipedia's articles they read with academic textbook written by academic experts.

\section{Lecturer's Role on Declining the Use of Wikipedia in Academic Essays}

In view of teaching student to appropriately use Wikipedia and avoid citing its articles as primary sources in their academic papers, some lecturers of the department applied firmed restriction to the use of Wikipedia in their student assignments. There were 39 student informants (out of 66 respondents to the item) in this study who confirmed such lecturer's restriction (Table 12). For the future time, there were relatively equal numbers of students who would still possibly use and cite Wikipedia's articles in their assignments (29 students) and who would not (30 students). Perhaps, there was a relationship between this trend and their experience of being marked by their lecturers (Table 13). Here, there were more students $(58.6 \%)$ who informed that most of their lecturers never deducted marks when they were proven to still cite from Wikipedia. Some students (21 persons) had experienced mark deduction when citing the online encyclopedia for their assignments. Most (12 of 21 students) of these unfortunate students only got $1-40 \%$ mark deduction while eight informants admitted to get $41-70 \%$ mark deduction because of still citing from Wikipedia, despite having been warned by the lecturer.

Table 12. Lecturer's role in limiting the use of Wikipedia for academic assignments / essays

\begin{tabular}{|c|c|c|c|c|c|}
\hline \multicolumn{3}{|c|}{$\begin{array}{l}\text { Is there any of your lecturers ever } \\
\text { prevent you from using material } \\
\text { taken from Wikipedia? }\end{array}$} & \multicolumn{3}{|c|}{$\begin{array}{l}\text { In the future, will you still cite from } \\
\text { Wikipedia for your assignment? }\end{array}$} \\
\hline Scale & Frequency & Percent & Scale & Frequency & Percent \\
\hline No & 27 & 38.6 & No & 30 & 42.9 \\
\hline Yes & 39 & 55.7 & Yes & 29 & 41.4 \\
\hline Total & 66 & 94.3 & Total & 59 & 84.3 \\
\hline
\end{tabular}


Table 13. Deterrence effect of the lecturers' restriction on Wikipedia usage

\begin{tabular}{|c|c|c|c|c|c|}
\hline \multicolumn{3}{|c|}{$\begin{array}{l}\text { Do you ever get lower score because of citing } \\
\text { from Wikipedia? }\end{array}$} & \multicolumn{3}{|c|}{ If yes, how low do you get? } \\
\hline Scale & Frequency & Percent & Scale & Frequency & Percent \\
\hline No & 41 & 58.6 & $1-40 \%$ & 12 & 17.1 \\
\hline Yes & 21 & 30.0 & $41-70 \%$ & 8 & 11.4 \\
\hline Total & 62 & 88.6 & $71-100 \%$ & 3 & 4.3 \\
\hline & & & Total & 23 & 32.9 \\
\hline
\end{tabular}

\section{Results of Interview with lecturers}

Unstructured interviews with eight lecturers of the department show surprising findings. In this preliminary investigation, there were four junior lecturers aged 26 to 31 and another four senior lecturers aged above 35 . The young lecturers were skillfully computer and internet literate. Although they were moderately good MS Excel users, they were very good at using MS Words and MS Power Point. They knew quite much about Wikipedia and the way to assess the quality of their students' academic writings. With regard to anticipating electronic plagiarism, these young lecturers had enough skill to detect it. They understood and consistently applied the concept of citing and referencing when assigning students to write. However, it was surprising to discover that, despite knowing the concept of citing, they did not know its English word for such acknowledging activity. Despite their awareness of electronic plagiarism, these young teachers still let their students cite articles from Wikipedia in academic writing. One of them argued that Wikipedia's articles in literary subjects were trustworthy enough. They only punished students who did not refer or cite when quoting but allowed students to cite from anything, including encyclopedias.

Furthermore, interviews with the senior lecturers reveal more astonishing facts. The senior lecturers already holding master degree apparently had insufficient computer and internet literacy. They admitted that they were not so much familiar with MS Words. They used it only for 'typing' instruments and were not enthusiastic in knowing more of the software's editing tools. Two of them simply knew MS Excel and MS Power Point but were not good at all in using them. In terms of internet literacy, two of them had email addresses but 'hardly' use them. Their knowledge about Wikipedia or electronic plagiarism was alarmingly at minimal level. They were completely in no disagreement on the use of Wikipedia as primary source in students writing. After being informed of the Wikipedia phenomenon, three of them began to be aware of this issue in their students' writing. They simply allowed several students citing Wikipedia's articles in their undergraduate thesis and going through the thesis exam in satisfactory result, in spite of feeling 'strange' with the student's excellent written English works. Moreover, they informed the interviewers that they hardly checked students' citations and references because what interested them more was the content of students' writings in their demonstration of comprehension. Citing from electronic source was a complicated matter for them thereby discouraging them from carefully assisting and assessing students on the matter.

In general, these lecturer informants knew the concept of citing and referring but did not consistently take them seriously in their assessment process. The absence of departmental guide on citation has become an obstacle and a source of 
debates when assessing the quality of students' writings, particularly undergraduate thesis. Moreover, their unawareness of the importance of consistently following a citation style in writing academically (especially in English) seems to have also led to their ignorance on this issue in student writings. Thus, students' electronic plagiarism has mostly not been detected and more importantly discouraged.

\section{DISCUSSION}

In general, the English department students' computer literacy and internet browsing literacy has proven to earn them a great help in completing their academic tasks. It is clearly seen that all participants of the study are computer and internet literate. The category good and very good in Table 1, 2 and 3 can be equally identified as confident. Thus, the good (58.6\%) and very good (34.3\%) students can be classified as confident MS Word users with a slight different level of confidence. Most of them are confident internet users too (Table 3). This means that the students generally know how to use all editing tools in the computer software in order to improve their writing quality. Combined with internet surfing ability, majority of these students seem to already have a long experience in copying-andpasting, editing and occasionally referring (38 persons in Table 10) to materials from internet for their assignments in a consistent citation style. In the absence of most of their lecturers' direct and strict guidelines on referencing and citing, the students continue to use this pattern of copying and pasting when writing their assignments. There is an indication that they recognize and take advantage of their lecturers' lower level of internet and computer skills.

One expected outcome is concerned with the students' MS Excel skill. As a department under the Faculty of Humanities, English department's students should certainly have to be competent users MS Words. In many subjects, they are mostly required to write arguments in the absence of statistical analysis. Lecturers in the department are not so much excited when dealing with numbers in their students' writings. Some of the students even make a joke by saying that they enter Faculty of Humanities because they never expect to see numbers anymore in the faculty, only letters. This also explains why most of them are not so confident (45.7\%) or not good (14.3\%) MS Excel user at all.

Another expected outcome is in terms of familiarity with internet access and using materials from internet. The participants all have email address and ever use internet to find information for their assignment. What is interesting from this finding is that most participants $(87 \%)$ who admit to cite from internet materials (Table 4) are also familiar with accessing Wikipedia (Table 8) partially due to the encyclopedia's speed and ease (Table 9). This finding confirms Schweitser's (2008) suggestion that many students tend to use the web as an official source of academic information. The result also confirms the facts that Wikipedia always becomes the first site from which any search engine can find articles for their user's order of enquiry (Baron, 2008; Cuhalev 2007 in Den Besten, Loubser, \& Dalle, 2008). It seems that the users are always offered to firstly look at information from Wikipedia other than from educational or academically reliable sites when browsing through web search engines.

In terms of strategy of using materials from Wikipedia in essays, the result of students' questionnaire inquiring their referencing strategies corresponds to the result of lecturers' interviews. According to the lecturers, there are three strategies 
in student plagiarism. The first strategy is by simply copying and pasting from electronic sources. The most frequent source is Wikipedia's articles. The second strategy is by editing after copying and pasting. The third strategy is by writing the introductory and conclusive paragraphs by themselves but simply copying and pasting Wikipedia materials into the body.

Most lecturers inform that they are aware of the three strategies simply by checking out the students' language. They would punish students only when they overwhelmingly copy and paste without referring. If students manage to considerably modify the materials by paraphrasing, the lecturers seem to ignore the quality of the source. Therefore, most students who appropriately paraphrase and cite Wikipedia materials without further checking out the quality of the article are free to go with good marks at many times in the absence of their lecturer's critical assessment. This may also result in an encouragement for some student informants to continue this practice in the future time.

Additionally, student informants' willingness to answer the question on frequency of using materials from internet in this study is different from SutherlandSmith's (2008) participants who were reluctant to answer (p.105). This may indicate a methodological differences or issues when surveying the participants in respective works. However, some informants' refusal to answer items related to frequency, strategy (Table 9, 10, 11) and consequence (Table 12 and 13) for using Wikipedia in their writing may confirm that they seem to carefully answer such investigative item because they will still have content subject classes where they are asked to submit written assignments, and an undergraduate thesis to write. Therefore, more future works on plagiarism or student writing strategy can include items investigating this phenomenon.

From the lecturers' side, primarily due to their un-upgraded citation skills, most informant lecturers find themselves in difficult time when assessing students' citation on electronic sources. Consequently, they often become less critical when assessing their students' papers. They commonly allow students to cite from Wikipedia. Only few students are punished for using Wikipedia as the primary source, mostly in Academic Writing class where the Wikipedia issue is openly discussed and critically examined. Students who seem to know the lecturer's ignorance have taken advantages of this gap and become practically smart. They seem to have learned their lesson by avoiding mere copy-and-paste strategy due to its susceptible detectability. In its place, the students edit and, where ever needed, paraphrase the sources and sometimes cites (depending on the lecturers to whom they would submit the paper). Such disagreement on consistently following a citation style among the lecturers may have encouraged student informants to become practical and opportunistic. This may become a backlash for the institution's educational goal. However, more comprehensive investigative works needs to be done on this issue in the future.

\section{Implications and suggestions}

This study results in the following related implications and suggestions:

1. There should be more extra computer trainings on the use MS Offices for students and, especially, lecturers thereby accelerating their academic work skills. 
2. More thorough investigations should be conducted on the department's student plagiarism strategies and techniques from either printed or electronic sources thereby alerting lecturers and the department on this issue.

3. English Department should formulate and consistently implement a policy of citation style of the department, especially when writing academically in English. Therefore, all lecturers will refer to the same citation manual when assessing student papers.

4. Consequently, there should be immediate trainings or workshops on electronic plagiarism in the department particularly for the lecturers. Without upgraded skills on citations, there is a slim chance that lecturers can affirmatively teach academic honesty to the students in academic writing.

5. There should be a consensus among lecturers concerning standards and proportions of assessment on student writings, such as essays and thesis. Therefore, students can no longer be opportunistic and selective in taking classes in relation to their lecturers because all lecturers will follow the same standard assessment mechanism on their written assignments.

6. Another potential research on the lecturers' and/or students' acquisition of different concepts of quoting and citing between English and Indonesian academic writings can be formulated in the future.

\section{CONCLUSION}

This study is intended to investigate the use of Wikipedia in English department students' writings. By collecting data from 70 sample students from around 500-600 registered student population at the department, it can be concluded that quoting and citing from electronic sources such as Wikipedia may widely be applicable. Students' techniques of quoting and referring have also been improved from merely copying-and-pasting into editing and paraphrasing. At this point, a positive result may be present in terms of students' academic writing skill of paraphrasing and editing. However, half of the informants do not cross check their Wikipedia sources partially due to either having no access to its links and books or lack of lecturers' control over their referencing quality. The eight lecturers being interviewed also informed of difficulty in assessing the papers due to the absence of departmental official policy on plagiarism. Lack of computer and internet skills also presents a degree of uneasiness for them to be aware of electronic plagiarism committed by their students despite their working knowledge of plagiarism from printed materials. Thus, despite being informed of the unreliability of Wikipedia as primary source in academic writing, students seem not to be deterred from using it because the department's lecturers are applying different policies when coming to the use of encyclopedia in academic writings.

\section{Limitations of this study}

This study suffers from at least three flaws. First of all, lack of samples of students' written assessed works in order to indicate students' strategies hampers the justification of the claims. Second of all, unstructured interviews with only few lecturers also pose a problem of quantitatively justifying the result generalization for the entire population. At last, some of the survey questionnaire items are not 
explorative enough due to its closed-ended selected nature. This prevents the survey from acquiring more possible alternative answers. Hopefully, further studies can benefit from this reflection.

\section{Acknowledgments}

The result of this investigation had been presented in the $44^{\text {th }}$ RELC International Seminar on the Impact of Technology on Language Learning and Teaching: What, How, and Why, Singapore, on 20-24 April 2009. We are truly grateful for the seminar participants valuable inputs and suggestions that had improved the final outcome of this research. We also thanked Universitas Andalas for the travel fund provided for us in that presentation.

\section{REFERENCES}

Adler, B. T, J. Benterou, K. Chatterjee, L. de Alfaro, I. Pye, and V. Raman. (2007). Assigning Trust to Wikipedia Content, Technical report UCSC-CRL-07-09, School of Engineering, University of California, Santa Cruz. Retrieved February 8, 2009, from http://works.bepress.com/luca_de_alfaro/5

Aharony, N. (2008). The use of Wiki in an academic course: A qualitative investigation: Proceedings of the the Informing Science \& IT Education Conference (InSITE) 2008, Informing Science + Information Technology Science Joint Conference, Varna, Bulgaria. Retrieved February 8, 2009 from http://proceedings.informingscience.org/InSITE2008/InSITE08p147153Aharony456.pdf

Andalas University. (2009). Undergraduate - Economics. Retrieved February 9, 2009

from http://www.unand.ac.id/en/index.php?pModule=academic\&pSub=econom ic\&pAct=view

Andalas University. (2009). Undergraduate - Letters. Retrieved February 9, 2009 from

http://www.unand.ac.id/en/index.php?pModule=academic \&pSub=letters\& pAct $=$ view

Baron, N. S. (2008). Always on: Language in online and mobile world. Oxford: Oxford University Press

Black E. W. (2008). Wikipedia and academic peer review: Wikipedia as a recognised medium for scholarly publication? [Abstract]. Online Information Review. 32 (1), 73-88.

Blumenstock, J. E. (2008). Automatically Assessing the Quality of Wikipedia Articles. School of Information. Paper 2008-021. Retrieved February 8, 2009 from http://repositories.cdlib.org/ischool/2008-021

Cohen, N. (2007). A history department bans citing Wikipedia as a research source. New York Times, February.

Cohen, N. (2007, February 21). A History Department Bans Citing Wikipedia as a Research Source. The New York Times, Education. Retrieved February 8, 2009,

from

http://www.nytimes.com/2007/02/21/education/21wikipedia.html?_r=1 
Cuhalev, J. Ranking of Wikipedia articles on search engines for searches about its own articles. In Den Besten, M., M. Loubser, \& J-M Dalle. (2008). Wikipedia as a Distributed Problem-Solving Network (November 17, 2008). OiI Working Paper,13. Retrieved February 8, 2009 from http://users.ox.ac.uk/ ierc0002/BLD08.pdf

Demartini, G. (2008). Finding experts using Wikipedia. In Zhdanova A. V. , L. J. B. Nixon, M. Mochol, and J. G. Breslin (Eds). Proceeding from Finding Experts on the Web with Semantic Workshops (FEWS2007). Retrieved February $\quad 8, \quad 2009 \quad$ from $\quad$ http://ftp.informatik.rwthaachen.de/Publications/CEUR-WS/Vol-290/paper03.pdf

Den Besten, M., M. Loubser, \& J-M Dalle. (2008). Wikipedia as a Distributed Problem-Solving Network (November 17, 2008). OII Working Paper, 13. $\begin{array}{llll}\text { Retrieved February } & \text { 8, } & 2009 & \text { from }\end{array}$ http://users.ox.ac.uk/ ierc0002/BLD08.pdf

Dornyei, Z. (2003). Questionnaire in second language research: Construction, administration, and processing. Mahwah, New Jersey: Lawrence Erlbaum Associates.

Foss, P., N. Carney, K. McDonald, M. Rooks. (2007). Project-Based Learning Activities for Short-Term Intensive English Programs. Asian EFL Journal: Professional teaching articles. 23, 78-91

James, R. \& C. McInnes. (2001). Standards oil tertiary debate. The Australian, Wednesday, August 15, p.28.

Mackey, A. \& S. M. Gass. (2005). Second language research: Methodology and design. Mahwah, New Jersey: Lawrence Erlbaum Associates.

Nielsen, F. ${ }^{\circ}$ A. (2007). Scientific citations in Wikipedia. First Monday, 12(8) $\begin{array}{llll}\text { retrieved } & \text { February } & \text { 8, } & 2009\end{array}$ http://arxiv.org/PS_cache/arxiv/pdf/0705/0705.2106v1.pdf

O'Connor, S. (2002). Electronic plagiarism and its impact on educational quality. Paper presented at the CAVAL electronic plagiarism conference (October 6), Melbourne, Australia.

Orlowski, A. (2006). Avoid Wikipedia, warns Wikipedia chief. It can seriously damage your grades. The Register. Retrieved February 13, 2009 from http://www.theregister.co.uk/2006/06/15/wikipedia_can_damage_your_gr ades/print.html

Page, J. S. (2008). Co-ordinating Peace Research and Education in Australia: A Report from the Canberra Forum of 2 May, 2008. Retrieved February 8, 2009 from http://eprints.qut.edu.au/15730/1/15730.pdf

Schweitzer, N. (2008). Wikipedia and Psychology: Coverage of concepts and its use by undergraduate students [Abstract]. Teaching of Psychology. 35(2):81-85.

Sutherland-Smith, W. (2008). Plagiarism, the internet, and student learning: Improving academic integrity. New York: Routledge

Wentz, R. \& V. Sharma. (2007). Using Wikipedia. Class handouts. Retrieved February 8, 2009 from http://hsclibrary.uchsc.edu/handouts/classhandouts/wikipedia.pdf 
Wikipedia: Academic use. (2009, January 6). In Wikipedia, the free encyclopedia. Retrieved February 13, 2009, from http://en.wikipedia.org/wiki/Wikipedia:Academic_use\#cite_note-0

Wikipedia: Citing Wikipedia. (2009, January 1). In Wikipedia, the free encyclopedia. Retrieved February 13, 2009, from http://en.wikipedia.org/wiki/Wikipedia:Citing_Wikipedia\#APA_style

Wikipedia: Researching with Wikipedia. (2009, January 8). In Wikipedia, the free encyclopedia. Retrieved February 13, 2009, from http://en.wikipedia.org/wiki/Wikipedia:Researching_with_Wikipedia

Wilkinson, M. D. \& B. A. Huberman. (2007). Quality and cooperation in $\begin{array}{lllll}\text { Wikipedia. } & \text { Retrieved } & \text { February } & 8 & 2009\end{array}$ http://www.hpl.hp.com/research/idl/papers/wikipedia/wikipedia07.pdf

Zobel, J. \& M. Hamilton. (2002). Managing student plagiarism in large academic departments. Australian Universities Review, 45(2), 23-30 


\section{Appendix 1}

\section{SURVEY QUESTIONNAIRE - STUDENTS}

This questionnaire is meant to investigate your efforts in writing / completing your assignment in college by using sources from internet. If you agree to participate in this research, please fill in the following questionnaire. Your personal information will be made completely confidential.

\section{Personal information:}

a. Student No / BP

b. Age

c. Sex

d. In what year are you now

e. What is your first language

*(circle which fits you)

"Hereby, I declare that I agree to participate in this survey and permit the researcher to use my information for the interest of the research."

\section{Computer and Browsing Literacy}

\begin{tabular}{|l|l|l|l|l|l|}
\hline No & \multicolumn{1}{|c|}{ QUESTIONS } & VG & G & NSG & NG \\
\hline 1. & $\begin{array}{l}\text { How good are you at using computer for completing } \\
\text { your assignment? }\end{array}$ & & & \\
\hline 2. & How good are you at using MS Word? & & & & \\
\hline 3. & How good are you at using MS Excel? & & & & \\
\hline 4. & How well are you in browsing internet? & & & \\
\hline $\mathrm{VG}=$ very good G = Good NSG = Not So Good NG = Not Good
\end{tabular}

\section{Using internet access in completing assignment}

\begin{tabular}{|c|c|c|c|}
\hline No & QUESTIONS & & \multirow{4}{*}{$\begin{array}{l}\text { No } \\
\text { No } \\
\text { No }\end{array}$} \\
\hline 1. & Do you have an email address? & \multirow{3}{*}{$\begin{array}{l}\text { Yes } \\
\text { Yes } \\
\text { Yes }\end{array}$} & \\
\hline 2. & $\begin{array}{l}\text { Do you ever use internet to find material for your } \\
\text { assignment? }\end{array}$ & & \\
\hline 3. & $\begin{array}{l}\text { Do you cite and refer when using material from internet for } \\
\text { your assignment? }\end{array}$ & & \\
\hline 4. & In percentage, how often do you use materials from internet? & & \\
\hline
\end{tabular}

\section{Using online encyclopedia in completing assignment}

\begin{tabular}{|c|l|l|}
\hline No & \multicolumn{1}{|c|}{ QUESTIONS } & \multicolumn{1}{|c|}{ Yes } \\
\hline \multirow{3}{*}{2.} & $\begin{array}{l}\text { Do you ever use online encyclopedia for getting information } \\
\text { to complete your assignment at college/university? }\end{array}$ & \\
\hline \multirow{2}{*}{2.} & $\begin{array}{l}\text { How many times do you use online encyclopedia for getting } \\
\text { information about your assignment at college? }\end{array}$ & \\
\hline & a. Every time & \\
\hline & b. Many times & \\
\hline & c. Sometimes & \\
\hline & d. Never & \\
\hline
\end{tabular}




\begin{tabular}{|c|c|c|c|}
\hline 3. & $\begin{array}{l}\text { What online encyclopedia that you commonly access for } \\
\text { information? } \\
\text { a. } \\
\text { b. } \\
\text { c. }\end{array}$ & \multirow{4}{*}{$\begin{array}{l}\text { Yes } \\
\text { Yes }\end{array}$} & \multirow{3}{*}{$\begin{array}{l}\mathrm{N} \\
\mathrm{N}\end{array}$} \\
\hline 4. & Are you familiar with accessing Wikipedia? & & \\
\hline 5. & $\begin{array}{l}\text { Do you ever use Wikipedia in completing your written } \\
\text { assignment? }\end{array}$ & & \\
\hline \multirow[t]{6}{*}{6.} & $\begin{array}{l}\text { If yes, do you use it to find (you may check more than one } \\
\text { answer): }\end{array}$ & & \\
\hline & a. The fastest and easiest references about content subjects & & \\
\hline & $\begin{array}{l}\text { b. The academically reliable information about content } \\
\text { subjects }\end{array}$ & & \\
\hline & c. The initial information about content subjects & & \\
\hline & d. $\quad$ The latest information about content subjects & & \\
\hline & $\begin{array}{l}\text { e. References (titles of more books / sources for my } \\
\text { assignments) }\end{array}$ & & \\
\hline \multirow[t]{7}{*}{7.} & $\begin{array}{l}\text { In what way do you use materials from Wikipedia to } \\
\text { complete your assignment? (please choose only the only } \\
\text { common way you usually use) }\end{array}$ & & \\
\hline & $\begin{array}{l}\text { a. Copy from the web page and paste into the } \\
\text { assignment }\end{array}$ & & \\
\hline & b. Copy, paste, and edit & & \\
\hline & c. Copy, paste, edit, and paraphrase & & \\
\hline & d. Copy, paste, edit, paraphrase, cite & & \\
\hline & e. Quote and cite & & \\
\hline & f. Cite & & \\
\hline 8. & $\begin{array}{l}\text { Do you ever find or further read books that are suggested to } \\
\text { be read or referred to by articles that you read from } \\
\text { Wikipedia? }\end{array}$ & \multirow{4}{*}{$\begin{array}{l}\text { Yes } \\
\text { Yes } \\
\text { Yes } \\
\text { Yes }\end{array}$} & \multirow{4}{*}{$\begin{array}{l}\text { No } \\
\text { No } \\
\text { No } \\
\text { No }\end{array}$} \\
\hline 9. & $\begin{array}{l}\text { Do you ever recheck the content of the articles that you read } \\
\text { from Wikipedia with the books written by the academic } \\
\text { experts? }\end{array}$ & & \\
\hline 10. & $\begin{array}{l}\text { Is there any of your lecturers ever prevent you from using } \\
\text { material taken from Wikipedia? }\end{array}$ & & \\
\hline 11. & $\begin{array}{l}\text { Do you ever get lower score because of citing from } \\
\text { Wikipedia? }\end{array}$ & & \\
\hline \multirow[t]{4}{*}{12.} & If yes, how low do you get? & & \\
\hline & a. $1-40 \%$ reduction & & \\
\hline & b. $41-70 \%$ reduction & & \\
\hline & c. $71-100 \%$ reduction & & \\
\hline 13. & $\begin{array}{l}\text { In the future, will you still cite from Wikipedia for your } \\
\text { assignment? }\end{array}$ & Yes & No \\
\hline
\end{tabular}

